\title{
Agronomy towards the Green Economy. Optimization of metal phytoextraction
}

\author{
Luca Marchiol, Guido Fellet \\ Dipartimento di Scienze Agrarie e Ambientali, Università di Udine, Italy
}

\begin{abstract}
Traditional techniques for remediation of polluted soils are based on a physical-chemical approach; such techniques are expensive, have adverse effects on soil quality and are often highly expensive. In the scenario of the Green Economy, low cost and impact technologies should be promoted. Phytotechnologies are remediation technologies that use plants for the containment, degradation or removal of contaminants from polluted matrices for the restoration of degraded ecosystems. The process of phytoextraction is substantially based on plantsoil interactions that involves the mass transfer of an inorganic pollutant from the bulk soil to the plant biomass. This implies that the management of the two elements of the system (plant and soil) should have effects on the efficiency of the process. As phytoremediation is essentially an agronomic approach, its success depends ultimately on standard agronomic practices. The present paper aims give an overview on the role of agronomy in the optimization of metal phytoextraction is focused.
\end{abstract}

\section{Introduction}

The recent oil spill in the Gulf of Mexico is only the latest in chronological sense of a series of events that confirm that humans have entered an unprecedented era of fast and possibly dangerous changes: the Anthropocene. First coined more than a decade ago (Crutzen and Stoermer, 2000), this term emphasizes the concept that human activities have such an impact on the ecosystems that may determine negative consequences on a global scale such as: global climate change and sharp increases in plant and animal extinctions.

Correspondence: Luca Marchiol, Dipartimento di Scienze Agrarie e Ambientali, Università di Udine, via delle Scienze 206, 33100 Udine, Italy. Tel.+39.0432.558611 - Fax +39.0432.558603. E-mail: marchiol@uniud.it

Key words: agronomy, green economy, soil pollution, phytoremediation, heavy metals.

Received for publication: 8 October 2010.

Accepted for publication: 8 July 2011.

CC Copyright L. Marchiol and G. Fellet, 2011

Licensee PAGEPress, Italy

Italian Journal of Agronomy 2011; 6:e30

doi:10.4081/ija.2011.e30

This work is licensed under a Creative Commons Attribution NonCommercial 3.0 License (CC BY-NC 3.0).
One of the several issues of Anthropocene is the release of large amounts of toxic and waste compounds into the biosphere. In China, the world's fastest-growing major economy, the problem of land pollution is a great challenge. In fact, one sixth of total arable land has been polluted by heavy metals, and more than $40 \%$ has been degraded to varying degree due to erosion and desertification (Lone et al., 2008).

In Europe, a number of 250,000 sites requiring remediation was estimated in 2007 by the European Environment Agency (EEA, 2007). This number is expected to grow considering that the number of potentially contaminated sites is about 3 millions (Figure 1a). Not to mention that there are also significant volumes of wastewaters and dredged polluted sediments. In the period 2001-2006 the number of sites awaiting for remediation increased by $150 \%$ and it is expected to increase by $50 \%$ by 2025 (EEA, 2007).

While this is a serious environmental issue that poses potential risks to the food chain and humans, it is also going to create the market of clean-up technologies. Estimates by EEA (2007) indicate that the annual budget invested for site investigation, remediation and management of contaminated lands is more than $2100 \mathrm{M} €$.

Although the range of polluting activities (and their relative importance as localized sources of soil contamination) may vary considerably across Europe, industrial and commercial activities, as well as the treatment and disposal of waste are reported to be the most important sources. Heavy metals and mineral oil are the most frequent soil contaminants occurring at the investigated sites (Figure 1b), while mineral oil and chlorinated hydrocarbons are the most frequent contaminants found in groundwater.

In Italy, more than 1 million ha, divided in 57 different sites, were included into the national list of polluted sites; this represents about $3 \%$ of the national territory. About 13,000 sites are likely to be included into the list and 4400 of these have already been proved to be contaminated. Within the National Polluted Sites List, lay the main industrial areas. According to some recent estimates, $30 \mathrm{M} €$ are necessary to remediate the national polluted sites (ISPRA, 2008).

\section{The Green Economy promotes green remediation}

The UNEP Green Economy Initiative is designed to assist governments in greening their economies by reshaping and refocusing policies, investments and spending towards sectors, such as clean technologies, renewable energies, water services, green transportation, waste management, green buildings and sustainable agriculture and forests. Science is expected to contribute producing new ideas and defining environmentally sound technologies able to sustain the Green Economy (UNEP, 2009).

The soil contamination by heavy metals and organics is of great concern due to its potential impact on human and animal health. The traditional soil clean up takes place by means of technologies based on a physicochemical approach. Such technologies include: solidifications and stabilizations, leaching of contaminants by using acid solutions, ion exchange due to electrokinetics, redox reactions and excavation and burial of the soil at a hazardous waste site. 
All the clean up technologies based on physicochemical approaches, are generally expensive being power consuming and have detrimental effects. The Green Remediation (GR) is the practice that considers all the environmental effects of a cleanup process during each phase, and incorporates strategies to maximize the net environmental benefit of the cleanup. The GR reduces the demand placed on the environment during the clean up actions, also known as the footprint of remediation, and avoids the potential for collateral environmental damage.

As reported by the USEPA (2008): GR results in effective cleanups minimizing the environmental and energy footprints of site remediation. Sustainable practices emphasize the need to more closely evaluate core elements of a cleanup project; compare the site-specific value of conservation benefits gained by different strategies of green remediation and weigh the environmental trade-offs of potential strategies.

The term phytotechnologies includes a variety of gentle techniques of environmental remediation that are currently being developed and will lead to contaminant degradation, removal, transfer or immobilization. The United Nations Environment Program defined the phytotechnologies as technologies relating to the use of vegetation, to resolve environmental problems in a watershed management, by prevention of landscape degradation, remediation and restoration of degraded ecosystems, control of environmental processes, and monitoring and assessment of environmental quality (UNEP, 2003).

Phytotechnologies are mainly applied in situ and can be applied to inorganic contaminants, such as heavy metals, metalloids, radioactive materials, and salts. Organic contaminants, such as hydrocarbons, crude oil, chlorinated compounds, pesticides, and explosive compounds, can be addressed using plant-based methods (ITRC 2009). Phytotechnologies potentially satisfy several aspects referred to the GR (USEPA, 2008) and have become attractive alternatives to conventional cleanup technologies providing environmentally friendly solutions for cleanup of contaminated soil and water, improvement of food safety, carbon sequestration, and development of renewable energy sources, all of which contribute to sustainable land use management (Schwitzguébel and Schröder, 2009).

Finally, the settlement and the maintenance of greeneries in polluted areas, other than the landscape aesthetical aspects, offer site-specific functional advantages such as: i) erosion prevention that might be

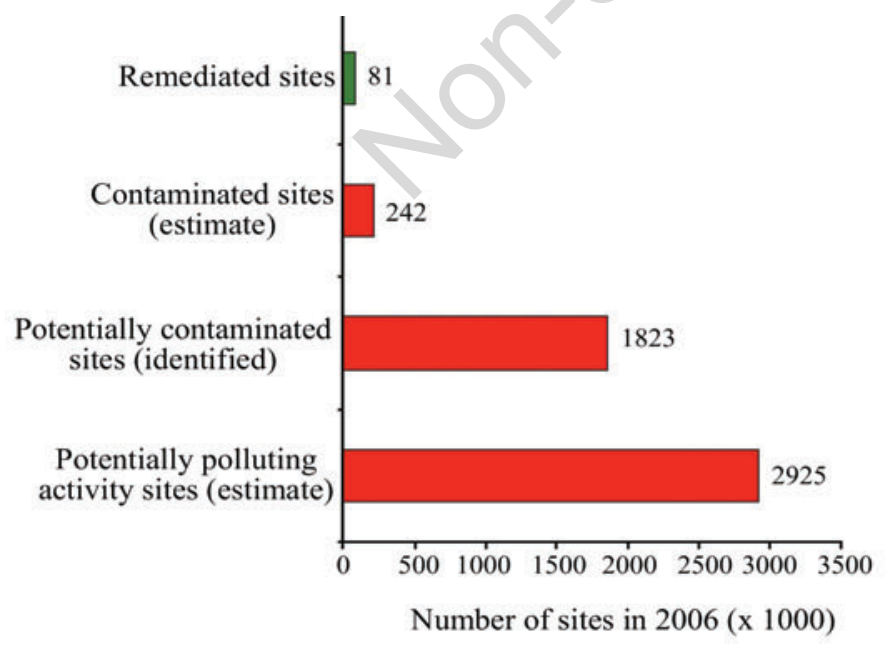

(a) responsible for the spreading of the pollutants; ii) a favorable hydrobalance that iii) significantly contribute to minimize the possible leaching of the contaminants.

\section{Phytoremediation}

From the origins to today

Although the relations between heavy metals and plants had been observed since five centuries ago, the idea that plants can be used for environmental remediation is relatively recent. Citing the godfather of hyperaccumulators, as was nicknamed Robert Brooks (1998) of Massey University in New Zealand, all began when a $16^{\text {th }}$ century Florentine botanist Andrea Cesalpino reported that he had noticed the ubiquitous presence of an alyson growing on the black stones (ultramafic rocks) in the Upper Tiber Valley in Tuscan. However, it was not until 1948, that was first reported nickel hyperaccumulation in the tissues of the serpentine plant Alyssum bertolonii (Minguzzi and Vergnano, 1948). This finding remained unknown until the middle 70's, when Brooks, made similar observations on other plants able to harvest metals such as gold and nickel from soil. If the research conducted by Brooks and colleagues appeared to have only academic interest, or possible application in biogeochemistry, this time the concept caught and suggested also the possibility of using this ability to develop new environmental services. Rufus Chaney - an USDA-ARS research agronomist - was the first to publish a report on the potential of hyperaccumulator plants for the cleanup of polluted sites (Chaney, 1983).

The term phytoremediation was first used in 1991 by Ilya Raskin from Rutgers University (NJ, USA) in a proposal funded by U.S. EPA Superfund Program on metals accumulation, whereas Cunningham and Berti (1993) first used this term in the literature. Table 1 illustrates how other remediation techniques compare to phytoremediation.

Basically, phytoremediation is categorized under sub-groups that correspond to mechanisms that enable plants to remove, destroy, transfer, stabilize, or contain contaminants (ITRC, 2009):

Phytoextraction: typically used to address metals, metalloids and radionuclides, involves the use of plants to remove contaminants from soil. The metals accumulated in the aerial parts can be removed by harvesting the biomass and disposed or burnt to recov-

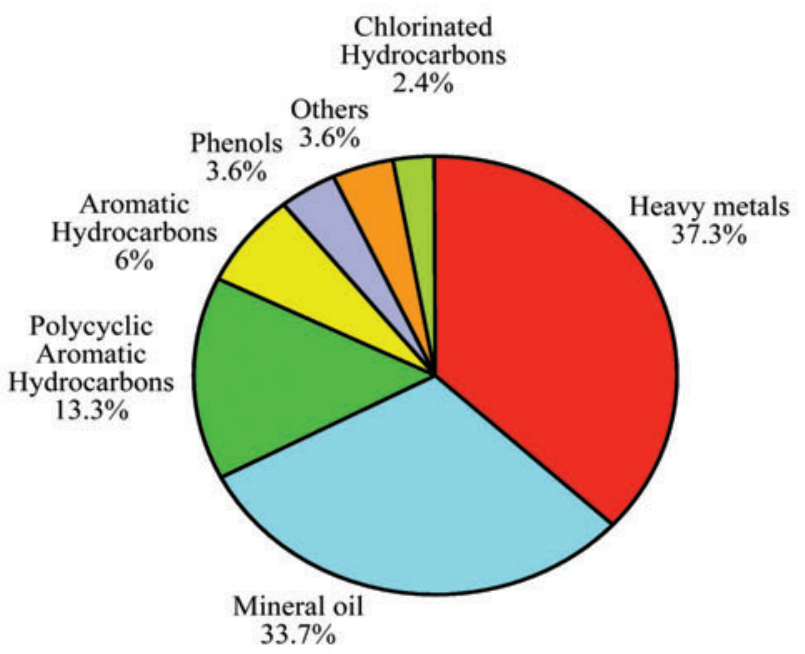

(b)

Figure 1. A) Overview of progress in the management of contaminated sites and B) contaminants affecting soil in Europe (modified from EEA, 2007). 
er metals. Biomass may require periodic harvesting and proper disposal to avoid metal release when the plants die or drop their leaves.

Phytostabilization: is a mechanism that immobilizes pollutants mainly metals - within the root zone, by adsorption at root level, formation of metal complexes, precipitation of metal ions. Phytostabilization does not require plant harvesting and disposal and can be also used to prevent migration of soil contaminants by wind and water erosion, soil dispersion, and leaching.

Phytodegradation: applicable to soils contaminated by organics (chlorinated solvents, herbicides, insecticides, PCBs). After the uptake, the pollutants are broken down within the plants to simpler, less persistent and dangerous compounds.

Phytovolatilization: is the uptake of a contaminant into a plant and its subsequent release to the atmosphere by transpiration, or the transformation of the contaminant which is then released into the atmosphere. Phytovolatilization can be applied to both inorganic (e.g., As, Hg, Se) and organic pollutants.

Rhizodegradation: the process is a plant-assisted bioremediation in which the root exudates, produced by the roots in the soil-root interface, enhance the metabolism of the soil microbial biomass thus increasing the breakdown of hydrocarbons, PAHs, pesticides, BTEX, chlorinated solvents and PCBs in the soil. In some instances, complete mineralization of the contaminant can occur.

Rhizofiltration: consists in the ability of plants to remove contaminants from water and aqueous waste streams. Absorption by plant roots play a key role in this technique, and consequently large root surface areas are usually required. The horizontal migration of groundwater can be controlled or contained using deep-rooted species, such as prairie plants and trees, to intercept, take up, and transpire the water.

About 30 years after the early abovementioned works on phytoremediation, dozens of labs in academia and industry are still working on phytoremediation and federal agencies began funding phytoremediation projects. The steep rise in scientific investigations and the knowledge explosion in phytotechnologies has been demonstrated by Prasad (2010) that reported as in May 2009, about 10,684 articles had been published on various aspects of phytoremediation when in 1989 only 11 were available. Nevertheless, the exciting prospects that were imagined some years ago have not been achieved, yet. Despite the worldwide intensive research, a significant gap between science and practical application so far exists (Dickinson et al. 2009).

\section{Claiming the role of agronomy}

In 2008 celebrating the centennial of the Agronomy Journal a special series of paper was published. Among them, a review by Miller (2008) entitled After 10,000 Years of Agriculture, Whither Agronomy? discussed the issues and challenges for agronomy in the next century. While traditionally agronomists work to improve crop productivity and the agronomic science deals with field-crop production and soil management, currently this vision should be enlarged.

Although the basic mission of agronomy cannot be abandoned, task ahead centers not only on the necessity to produce food, but whether agronomists can deliver this productivity in an ecologically sustainable manner through socially accepted production systems (Miller, 2008).

Lichtfouse et al. (2010) considered that agronomy should not be reduced to a science that improves crop yields but should answer all society's issues because agriculture is both the foundation and the future of society. Agronomists should rethink the role of agriculture in our society. Moreover (again Lichtfouse et al., 2010), mainstream goals should be challenged and rethought to take into account other factors. Those factors should not be solely defined by classical agrosciences (e.g., plant and soil sciences, but should also include all other sciences that really rule agriculture; for instance, ecological, economic, social and political sciences.

Some significant examples of this ongoing transformation are represented by the biofuels, and the plant molecular farming. However, another example corresponds to what was predicted by Chaney almost 30 years ago. Agronomy is going to gain new perspectives for applications in the field of environmental services. In fact, as regard phytotechnologies, agronomy has a fundamental role in the management of phytoremediation systems. Referring to phytoextraction, the efficiency of the system for a given species is determined by two key factors: biomass production and the metal bioaccumulation factor. Therefore, it could be concluded that: i) phytoremediation is essentially an agronomic approach and ii) its success depends ultimately on agronomic practices whose effects on plant/soil/contaminant interaction would optimize phytoremediation process to site specific conditions. This kind of experience can only be provided by technicians trained by the science of agronomy.

It was not by chance that the utilization of plants for the soil cleanup of polluted sites was first proposed by an agronomist.

\section{Designing and managing phases}

The designing and managing phases in phytoremediation systems are similar to any in situ remediation technique. Different competences are necessary to properly evaluate and understand the technical parameters of the process. Table 2 summarizes the different phases that require specific skills (ITRC, 2009). Considering that it is unrealistic that all these skills are embodied in one person, a multidisciplinary team should be composed as follows:

Project Manager. Evaluates the phytoremediation system versus alternatives by considering the cleanup objectives, contaminant remediation mechanisms, sampling and analysis plan, operation and maintenance plan, health and safety plans, schedules, compliance, and cleanup time. Ensure that health and safety requirements are in place and adhered to lasting field activities. The manager has the responsibility of assessing the costs of intervention in relation to the available budget before and throughout the project.

Risk Assessor/Toxicologist. In the project design phase, evaluates the

Table 1. Comparing other remediation techniques to phytoremediation.

\begin{tabular}{lll} 
Treatment & Advantages compared to phytoremediation & Disadvantages compared to phytoremediation \\
Solidification & $\begin{array}{l}\text { Not seasonally dependent; methods well established } \\
\text { for most metals and organics; simple to operate. }\end{array}$ & Site not restored to original form; can result in a significant volume increase. \\
Soil washing & $\begin{array}{l}\text { Not seasonally dependent; methods well established } \\
\text { for several types of sites and contamination. }\end{array}$ & pH change required; additional treatment steps add complexity and cost. \\
\hline Electrokinetics & Not seasonally dependent. & Useful for soil only, not wetlands; uniformity of soil conditions is required. \\
Redox & $\begin{array}{l}\text { Not seasonally dependent; relatively short treatment } \\
\text { time frame. }\end{array}$ & Requires excavation; uses chemical additives; soil fertility may be damaged. \\
\hline Excavation/ & Rapid/immediate solution for site owner. & Transfers contaminants to landfill; does not treat. \\
Disposal & &
\end{tabular}


ecological and human health risks of using phytotechnologies and compare them to the risks associated to implementing one of the alternatives.

Regulatory Specialist. Determines the regulatory requirements, final cleanup limits, sampling and analysis requirements and handling and disposal of any generated wastes (air emissions, effluents, solid wastes and plant biomasses). Maintains the relationships with the public authorities.

Agronomist. Evaluates the ability of the soil conditions to support plants. Develops both a soil amendment and fertilization plan to prepare and maintain the growth of plants throughout the duration of the phytoremediation application. Should have specific knowledge about the plant species capable of remediating the contaminants of concern and suitable for the site soil, groundwater, and climatic conditions. Determine planting requirements, including density, patterns, field preparation, and equipment needs.

Environmental Engineer. In the design phase, evaluates the preparation of the site considering earthmoving operations, materials and implementation of monitoring systems. Other aspects specifically related to the management of plantations such as irrigation and drainage systems, water control, isolation systems, wells monitoring systems should be evaluated in collaboration with agronomists.

\section{Optimizing agronomic management: the open issues for phytoextraction}

To date, market expectations have been disappointed. Therefore the development and subsequent optimization of phytotechnologies should be still considered a goal. This applies especially to phytoextraction that is the most fascinating and complex option among those offered by phytotechnologies and, for these reasons, it is chosen here as paradigm. Dickinson et al. (2009) summarized the weak points of the fieldphase of phytoextraction and more recently a significant review by Mench et al. (2010) reported an up-to-date discussion based on literature and the findings of the members of COST Action 859.

The process of phytoextraction is based substantially on the mass transfer of an inorganic pollutant from the bulk soil to the plant biomass. This plant-soil interaction implies that the management of the two elements of the system (plant and soil) should have effects on the efficiency of the process. The success of phytoremediation depends ultimately on the standard agronomic practices (corresponding to Operation/Maintenance/Monitoring phase in Table 2) such as plant species selection, specific soil management practices, fertilization, irrigation and weed and pest control. Moreover, as it is a long-term remediation effort, many cropping cycles to decontaminate metal pollutants to acceptable levels are required, thus appropriate and effective schemes of crop rotation should be available.

\section{Plant species selection}

One of the key questions for phytoextraction is which plant species should be used. The plant selections must be based on site-specific conditions: concentration of contaminant(s), depth of contamination, climate, altitude, soil salinity, nutrient content, fertility, and plant hardiness which are the main determining elements. For such a variety of conditions, information resources, technical databases, site-specific vegetation surveys, and specifically designed tests should be available to evaluate the species.

Beyond the expected performances of plants against pollutants, it might be interesting to consider plants that can also provide some kind of employement and not simply to be disposed as polluted wastes. In this way, phytoextraction could gain more economic value. Some examples regards i) the cultivation of biomass crops whose metal-rich ash may be suitable for smelter feedstock or ii) for metal removal (Chaney et al., 2007), composting, production of biofuels, extraction of oils and essential oils (Dickinson et al., 2009, Vangrosveld et al., 2009; Vamerali et al., 2010).

So far, three options should be considered: i) cultivation of arable crops, with/without chelating agents; ii) cultivation of rapidly growing metal-accumulating phenotypes of trees to produce biomass for energy generation or other financial returns and iii) cultivation of hyperaccumulators.

It is known that hyperaccumulators tolerate, grow and reproduce themselves in highly polluted soils. For these reasons, they were once considered potentially highly suitable for phytoextraction. However, several drawbacks exist. Hyperaccumulators are highly adapted to adverse soil conditions, generally grow slowly and produce little biomass. This low biomass production precludes their use at a large scale level. Finally, hyperaccumulators are highly selective having a metabolism adapted to an excess of a single or two elements. Neither hyperaccumulator rotations nor intercroppings can be imagined. Non-hyperaccumulating metal tolerant plants that may be used for phytoextraction can generally be cultivated using established agronomic practices (Mench et al., 2010).

Based on these general considerations the initial question perhaps should be changed into the more appropriate one: which plants can lead to an effective phytoextraction with sustainable ecological and/or financial returns? The answer could be strongly influenced by the willingness of stakeholders to support the cost/benefits ratio with an additional income.

Finally, we cannot ignore an issue that will soon become very important: the potential of biotechnologies. In brief, there is a general agreement on the fact that the potential of biotechnologies is very high and transgenic plants might be able to contribute to the wider and safer large-scale application of phytoremediation (Hong-Bo et al., 2010). At the moment, the legislative barriers block their release into the environment. However, it is likely that the use of plants as genetically engineered environmental cleanup biosystems might also help to overcome the legislative barriers and to support the public into improving their opinion on transgenic plants that is currently quite low (Macek et al., 2009).

\section{Specific soil management practices}

Rather than the traditional operations of seedbed preparation, in this case as the set of soil management practices should be intended

Table 2. Phytoremediation system: required skills for project phases (modified from ITRC, 2009).

\begin{tabular}{lccccc} 
Discipline & Assessment & Selection & Design & $\begin{array}{c}\text { Implementation } \\
\text { Operation } \\
\text { Maintenance } \\
\text { Monitoring }\end{array}$ \\
Project management & $\square$ & $\square$ & $\square$ & $\square$ & $\square$ \\
Risk assessment/toxicology & $\square$ & $\square$ & & & $\square$ \\
\hline Regulatory interpretation & $\square$ & $\square$ & & $\square$ & $\square$ \\
Agronomy & $\square$ & $\square$ & $\square$ & $\square$ & $\square$ \\
\hline Environmental engineering & & $\square$ & $\square$ & $\square$ \\
\hline
\end{tabular}


the term practices, that characterize the assisted-phytoextraction. The soil addition of natural and/or synthetic chelators has been extensively experimented in phytoextraction, in order to increase metal bioavailability, uptake and translocation of metals. This goal may be achieved by adding both inorganic and organic agents to the soil, although the latter appears to be more effective in increasing the metal solubility (Vamerali et al., 2010).

When chelating agents or similar chemicals are used to mobilize contaminants to promote or enhance the phytoextraction, several factors must be considered beforehand, including the method of application - usually through an irrigation system - the weather conditions, the stage of plant development, the rate of application versus the rate of water usage, and the potential to increase the risk of exposure. It is highly recommended to schedule the harvesting activity immediately or shortly after the application of the mobilizing chemical (ITRC, 2009).

This practice works when the metal to be extracted is initially of very low bioavailability, and thus not phytotoxic, allowing the establishment of a large plant biomass before the chelator is applied. Otherwise the plant dies and the amount of metal that has been mobilized cannot be absorbed by the plant. The more efficient the chelators are, the higher risks of plant toxicity. For this reason, a scientific controversy has risen on assisted phytoextraction in relation to the environmental concern due to uncontrolled metal mobilization in soil and consequent risks of secondary pollution of the groundwater. On the other hand, synthetic chelating agents (e.g., EDTA, NTA and EDDS) were themselves phytotoxic. An efficient alternative to synthetic chelators is the use of biodegradable low-molecular-mass organic acids (Lasat, 2002).

\section{Soil amendment, fertilisation and irrigation}

Since phytoremediation strategies are often implemented in nutrient-poor soils - in which nitrogen and phosphorus are generally limiting (Olson et al., 2008) - or characterized by other anomalous conditions (pH imbalances, salinity), a preliminary assessment could give adequate information about the most appropriate agronomic practices that can create the best environmental condition for crops. To maintain vigorous plant growth, development, and health, optimum soil nutrient level need to be maintained and monitored periodically throughout the life of the remediation project. The soil conditions must always be assessed before starting the soil remediation project and eventually monitored frequently, several times per year in the most critical conditions to only every few years (IRCT, 2009). In Table 3 the potential amendment remedies are summarized for various soil conditions and plant growth needs.

Agronomists are able to assess the nutrient needs based on the chosen crops, the soil conditions and during the plant growth cycle by monitoring indicators obtained from the plants themselves, such as wilting, yellowing and leaf curling that can often be traced to specific nutrient deficiency and toxicity.

In addition to the soil nutrient content, water supply also needs to be at optimum conditions. Considering the potential risks of pollutant mobilization, this practice should be managed carefully. A site water balance should be studied considering the natural rainfall, the crop transpiration and the water holding capacity (ITRC, 2009).

\section{Crop rotation and intercropping}

The main goal of any remediation technique is to achieve the soil clean up target in the shortest time. Phytoremediation, using biological tools, is naturally limited by climate conditions. The use of a single species (even an hyperaccumulator) cannot guarantee a continuous soil covering and metal uptake. On the other hand, phytoremediation should be continuous and efficient for the longest possible time thus the soils should not be left bare after harvesting the crop. Moreover, since phytoremediation is a long-term strategy, both crop rotations and intercroppings should be considered.
Table 3. Potential amendment remedies for various soil conditions/growth needs (modified from ITRC, 2009).

\begin{tabular}{|c|c|}
\hline $\begin{array}{l}\text { Soil condition } \\
\text { or effect }\end{array}$ & Soil amendment \\
\hline General fertility & $\begin{array}{l}\text { Balanced NPK fertilizer, biosolids, sewage } \\
\text { sludge }\end{array}$ \\
\hline Root development/growth & Phosphate fertilizer, ectomycorrhizal fungi \\
\hline Foliar growth & Nitrogen fertilizer \\
\hline Nutrient regulation & Potassium fertilizer \\
\hline Essential metals & $\begin{array}{l}\text { Ectomycorrhizal fungi, chelating agents, } \\
\text { weak acids }\end{array}$ \\
\hline Acidity $(\mathrm{pH}<5)$ & Lime \\
\hline Alkalinity $(\mathrm{pH}>9)$ & Gypsum, sulfur \\
\hline $\begin{array}{l}\text { Salinity }(\mathrm{EC}>4 \mathrm{mS} / \mathrm{cm}) / \\
\text { Sodicity }(\mathrm{SAR}>12 \mathrm{meq} / \mathrm{L})\end{array}$ & $\begin{array}{l}\text { Gypsum, calcium/magnesium fertilizer } \\
\text { (+ irrigation) }\end{array}$ \\
\hline Water holding capacity & Compost/mulch mixed in \\
\hline $\begin{array}{l}\text { Moisture retention / } \\
\text { Temperature regulation }\end{array}$ & Compost/mulch on surface \\
\hline
\end{tabular}

The use of a variety of vegetation leads to a greater chance of success and is preferred over monocultures due to the following advantages: i) mixed stands may lose only one or two species to a disease, while monocultures may be entirely susceptible so that one event can destroy the entire phytotechnology system; ii) intercropping support more diverse microbial communities that possibly promote an enhancement of the process; iii) synergistic effects such as nutrient cycling can occur in mixed stands; iv) the biodiversity and potential habitat restoration qualities are promoted; $v$ ) a higher volume of soil is explored by roots, then root metal uptake can contemporary occur at different soil depths.

Although this is of some importance, a little research have been done. After the promising early information provided by Gove $e t$ al. (2002) the issue was poorly investigated. However recent papers by $\mathrm{Li}$ et al. (2009), Dhillon and Dhillon (2009) and Nie et al. (2010) confirm that intercropping and rotations might be a feasible practice in phytoremediation. Unfortunately, Mench et al. (2010) did not report any data about the field trials on crop rotation or intercropping, thus, this issue is still open.

\section{Weed and pest control}

Weeds should be controlled to reduce competition with the selected plants and prevent the spread of not effective plants. They can be controlled by the traditional mechanical or chemical methods (ITRC, 2009). Herbicides can be applied before or after the emergence of the phytoremediating species. Application of pre-emergence herbicides ensures good weed control, quick emergence, and establishment of selected plants. Post-emergence herbicides control weeds that emerge later in the growing season, as occurs in traditional food-agriculture (Lasat, 2002). Nevertheless, the importance of this practice is strictly related to the species considered for phytoremediation. It is likely that it is particularly important when using hyperaccumulators. From an ecological point of view they are highly specialized to grow in anomalous soils where other species are not able to survive and thus would be less competitive than other species in slightly polluted soils. Biomass crops in polluted soils may have slower growth rates than those recorded in optimal conditions; on the other hand it was noted that several weeds have an intrinsic tolerance against some adverse factors, and between these, the soil pollutants (Wei et al., 2008; Dhillon and Dhillon, 2009).

Regarding the pest control, if their management for the biomass crops is known, we lack any information for the hyperaccumulators. It 
is likely that being wild plants are more resistant than crops. However, also in this case Mench et al. (2010) did not report any data about field trials on the enhancement of phytoremediation as a consequence of the pest control to the field management practices.

\section{Harvesting and handling biomass}

Both the operations deal with respectively the field and the closure phases of a phytoremediation project (Table 2). Mowing crops and pruning/thinning trees are generally carried out using standard equipment such as mowers, clippers, shears, rotary trimmers and chainsaws (ITRC, 2009).

The plant material generated may need to be collected and treated as if it was an hazardous waste until appropriate testing for contaminant accumulation can be conducted. Even if the plant waste is not classified as a hazardous waste, it may be sufficiently contaminated to require special handling according to some national laws.

If the phytoremediation project does not result in contaminated biomass, the plant material may be harvested and sold as a cash crop to offset some of the remedial costs. Several options exist, including using the biomass as an energy source (direct-fired or as a biofuel feedstock), recovering inorganic constituents (i.e., precious metals) from the plant tissues, or supplementing animal feed supplies (Chaney et al., 2007).

If the plant species selected is efficient, the higher the biomass removed from the site, the greater the proportion of contaminant removed. Assuming that harvesting operations are managed under safe conditions not exposing the workers to health risks, the strategy by which the plant biomasses are harvested is not a technical problem. Currently the problem, that must be still solved, is related to the available post-harvesting biomass disposal options: this is one of the problems inhibiting the widespread use of this remediation technique (Stals et al., 2009).

To decrease handling, processing, and potential landfilling costs, waste volume can be reduced by thermal, microbial, physical, or chemical means (Lasat, 2002). Only in the case of radionuclide phytoremediation it is clear that the contaminants in biomass will require expensive post harvest disposal of contaminated biomass (Chaney et al., 2007).

\section{A field experience in North-eastern Italy}

About 10 years ago, we started working in this field together with other groups within the framework of several projects. The most significant work that we managed in this period was the field experiment of metal phytoextraction. That work was an exciting challenge that make us very proud for testing our expertise at a field scale to counteract a problem for the good of the community. This activity had also a relevance from a scientific point of view, being the first Italian in situ phytoremediation trial. For details see Fellet et al. (2007) and Marchiol et al. (2007).

Unfortunately, we experienced some discouraging administrative problems with the public administrations. The field experiment, financed by public funds, was considered by the public administration as a kind of industrial plant of waste treatment. Hence, a lot of permissions were requested and a lot of time was spent to manage the requirements, and we were not allowed to maintain the field trial for more than three years.

Considering that the public administration is usually the main beneficiary for innovative and less expensive clean up technologies, we wish that in the next future there will be a less hostile relationships between science and administration. Perhaps, this problem should be addressed at EU level making it simpler to perform such kind of research activity at large-scale. The efforts and investments devoted to the lab research should be oriented supporting field scale investigations considering that sometimes the complexity is so high as to weak- en the validity of the results obtained by lab experiments.

The research overview performed by Mench et al. (2010) confirmed what we experienced, in fact they stated that the gap between research and development for the use of phytoremediation options at field level is partly due to a lack of awareness by regulators and problem owners, a lack of expertise and knowledge by service providers and contractors and uncertainties in long-term effectiveness. Multidisciplinary research teams and a meaningful partnership between stakeholders are primary requirements to be gained for the social and financial sustainability of phytotechnologies and to demonstrate their efficiency for the solution of large-scale pollution problems.

\section{What has been done and future prospects}

A great deal of progress has been achieved at experimental level for several options offered by phytotechnologies. Several comprehensive reviews by Chaney et al. 1997, McGrath and Zhao 2003, Pilon-Smits 2005, Vangronsveld et al., 2009, Wu et al., 2010 and Krämer 2010, summarized many important aspects of this plant-based technology and reported the achievements of the scientific community. However, at this moment, we are still far from a large scale application of the phytotechnologies.

The excessive process length is the main limiting factor. To one hand, this duration - the Achilles' heel of phytoremediation (Van Nevel et al., 2007) - is particularly unacceptable when we consider an area which must be urgently restored for other purposes. On the other hand, the negative public hype of phytoremediation (the duration of the process) is perhaps perceived in excess than what it is because of disproportionate early expectations.

Currently, phytoremediation technologies are neither fast nor efficient as the market of soil clean up technologies expects. Also, the economic case to support it, is often marginal and the time required for phytoremediation may be unrealistic. The commercial application of phytoremediation as a practical site solution is yet considered not feasible (Onwubuya et al., 2009). The initial enthusiasms on phytoremediation recorded in the middle 90's was disappointed. It is likely that the actual complexity of the problem was underestimated. However, in our opinion, the significant amount of experience worldwide gained should not be lost. Further investments of intellectual and financial resources will overcome the current problems restoring a real applicative potential to phytoremediation. With regard to the expected performances of phytotechnologies, let us take into account two applications: phytoextraction and phytostabilization. From a practical point of view, perhaps the first one is the most fascinating and (theoretically) efficient between the different options offered by phytotechnologies. The second one has been already successfully tested and it is available for extensive projects.

Regarding phytoremediation, despite the intensive research in the last decade, another widening gap between science and practicality lays on the fact that very few field trials to demonstrate the feasibility of the phytotechnologies have been realized. So far, unrealistic field scale extrapolations from experimental data from lab and greenhouse trials have raised doubts about the feasibility of metal phytoextraction (Dickinson et al. 2009).

For further development, social and commercial acceptance, there is a clear requirement for up-to-date information on successes and failures of these technologies based on evidence from the field scale.

An inventory of the field trials performed in Europe in the years 2000-2008 indicated that 25 field trials took place in 9 European countries (SUMATECS, 2009). The phytoextraction potentials were evaluated, studying biomass species and, to a lesser extent, hyperaccumulators (Table 4).

Unlike phytoextraction, phytostabilization is not intended to remove metal contaminants from a site, but rather to stabilize them by the accumulation in roots or the precipitation within the rhizosphere, 
Table 4. European inventory of field trials of metal phytoextraction (SUMATECS, 2009).

\begin{tabular}{|c|c|c|c|}
\hline Element & Species & State & Place \\
\hline $\mathrm{Cd}, \mathrm{Cr}, \mathrm{Cu}, \mathrm{Ni}, \mathrm{Pb}, \mathrm{Zn}$ & S. viminalis & B & Menen $^{1,2}$ \\
\hline $\mathrm{Cd}, \mathrm{Cu}, \mathrm{Zn}$ & Q. robur, P. alba, A. pseudoplatanus & & Deinze $^{3}$ \\
\hline $\mathrm{Cd}, \mathrm{Cu}, \mathrm{Zn}$ & $\begin{array}{l}\text { S. viminalis, } N \text {. tabacum, } H \text {. annuus, } B . \text { juncea, } Z \text {. mays, T. caerulescens } \\
\text { B. pendula, S. viminalis, } A \text {. incana, F. excelsior }\end{array}$ & $\mathrm{CH}$ & $\begin{array}{l}\text { Dornach, Caslano }{ }^{4,5} \\
\text { Le Locle }^{6}\end{array}$ \\
\hline $\mathrm{Cd}, \mathrm{Pb}$ & Z. mays & $\mathrm{CZ}$ & Pribram ${ }^{7}$ \\
\hline $\mathrm{Pb}$ & Pelargonium cvs & $\mathrm{F}$ & Bazoches $^{8}$ \\
\hline $\mathrm{Cd}, \mathrm{Zn}$ & T. caerulescens & & La Bouzule ${ }^{9}$ \\
\hline $\mathrm{As}, \mathrm{Cu}, \mathrm{Cd}, \mathrm{Co}, \mathrm{Pb}, \mathrm{Zn}$ & H. annuus, S. bicolor, Salix spp., Populus spp. & I & Torviscosa ${ }^{10,11}$ \\
\hline $\mathrm{Cd}, \mathrm{Zn}$ & B. napus & NL & Budel $^{12}$ \\
\hline $\mathrm{Cd}, \mathrm{Cr}, \mathrm{Cu}, \mathrm{Ni}, \mathrm{Pb}, \mathrm{Zn}$ & S. viminalis & $\mathrm{S}$ & Uppsala, Enkóping ${ }^{13,14}$ \\
\hline $\mathrm{Pb}, \mathrm{Zn}, \mathrm{Cu}, \mathrm{Cd}$ & B. carinata, $B$. juncea & SP & Aznalcollar ${ }^{15}$ \\
\hline $\mathrm{Pb}, \mathrm{Sb}, \mathrm{Tl}, \mathrm{Zn}$ & O. europea, P. alba, Mediterranean shrubs & & Aznalcollar ${ }^{16}$ \\
\hline $\mathrm{Cd}, \mathrm{Zn}$ & T. caerulescens, A. halleri & UK & Bedfordshire $^{17}$ \\
\hline $\mathrm{As}, \mathrm{Cd}, \mathrm{Cu}, \mathrm{Ni}$ & Betula spp. & & Liverpool $^{18}$ \\
\hline $\mathrm{Cu}$ & Alnus spp, C. monogyna, S. caprea & & Merseyside $^{19}$ \\
\hline $\mathrm{Cd}, \mathrm{Cu}, \mathrm{Ni}, \mathrm{Zn}$ & Salix spp. T. caerulescens & & Nottingham ${ }^{20,21}$ \\
\hline $\mathrm{Cd}, \mathrm{Cu}, \mathrm{Zn}$ & Salix spp. & & Warrington $^{22}$ \\
\hline
\end{tabular}

reducing the risk to the human health and the environment. It is applicable in scenarios where there is a potential risk of human health impacts, and the exposure to hazardous substances may be reduced to acceptable levels by containment. That is the case of highly polluted areas, where the removal of metals by phytoextraction using hyperaccumulators or crops is not efficient (Dickinson et al., 2009). Phytostabilization is also advantageous when decontamination strategies are impractical because of the extent of the contaminated area or the lack of adequate funding (Santibáñez et al., 2008). It may also serve as an interim strategy to reduce the risk at sites where complications delay the selection of the most appropriate technique. A typical scenario in which phytostabilization could be considered is represented by the anthropogenic metalliferous sites (e.g., abandoned mining sites, smelter sites) where the presence of wastes and mine tailings can result in severe pollution and have anesthetic impacts on the local environment.

\section{Conclusive remarks}

Further progresses on phytoextraction are expected to be done on the following research lines and activities:

- understanding, at biochemical and molecular levels, of mechanisms and their regulation related to uptake-exclusion, apoplastic barriers, xylem loading, root-to-shoot transfer, concentration, storage and detoxification for plants;

- evaluating microbial or fungal symbiosis that may improve the plant metal uptake;

- useing of hormones or other substances to modify the plant metabolism in order to improve the metal translocation;

- breeding between hyperaccumulators and tolerant species and genetic engineering of plants to create high efficiency and high biomass plants;

- increaseing the resolution and accuracy of the genetic mapping of loci for metal hyperaccumulation and hypertolerance;

- extending the research from model species to plants of economic importance and including interactions between plants and microorganisms.

- defining agronomic practices to improve the phytoextraction process efficiency of hyperaccumulators and biomass crops, also by changing the metal bioavailability;

finding further uses of the biomass to improve the sustainability of the technique;

developing long-term field trials.

In conclusion, a lot of work is expected to be done to improve the efficiency of the process, particularly focusing towards the most appropriate agronomic management of it. This work must be done in field conditions, otherwise misleading results and indications may arise, bringing negative consequences and the prospects of phytoremediation would likely be further damaged (Meers, 2010; Mench et al., 2010).

The ultimate goal is to create, develop, and scale up phytotechnologies to the market level and to successfully deploy these to ameliorate the environment and human health. In short, one of the ways in which agronomy can contribute to the Green Economy.

\section{References}

Arshad M., Silvestre J., Pinelli E., Kallerhoff J., Kaemmerer M., Tarigo A., Shahid M., Guiresse M., Pradere P., Dumat C., 2008. A field study of lead phytoextraction by various scented Pelargonium cultivars. Chemosphere 71:2187-2192.

Brooks R.R., 1998. Plants that hyperaccumulate heavy metals. CAB International, Wallingford, UK.

Chaney R.L., 1983. Plant uptake of inorganic waste constituents. In: J.F. Parr, P.B. Marsh and J.M. Kla (eds.) Land Treatment of Hazardous Wastes. Noyes Data Corp. Publ., Park Ridge, NJ, USA.

Chaney R.L., Angle J.S., Broadhurst C.L., Peters C.A., Tappero R.V., Sparks D.L., 2007. Improved understanding of hyperaccumulation yields commercial phytoextraction and phytomining technologies. J. Env. Qual. 36:1429-1443.

Chaney R.L., Malik M., Li Y.M., Brown S.L., Brewer E.P., Angle J.S., Baker A.J.M., 1997. Phytoremediation of soil metals. Curr. Opin. Biotechnol. 8:279-284.

Crutzen P.J., Stoermer E.F., 2000. The Anthropocene. Global Change 
Newsletter 41:17-18.

Cunningham S.D., Berti W.R., 1993. Remediation of contaminated soils with green plants: an overview. In Vitro Cell. Develop. Biol. 29:207212.

del Río M., Font R., Fernández-Martínez J.M., Domínguez J., de Haro A., 2000. Field trials of Brassica carinata and Brassica juncea in polluted soils of the Guadiamar river area. Fres. Env. Bull. 9:328-332.

Dhillon S.K., Dhillon K.S., 2009. Phytoremediation of selenium-contaminated soils: the efficiency of different cropping systems. Soil Use Manage. 25:441-453.

Dickinson N.M., 2000. Strategies for sustainable woodlands on contaminated soils. Chemosphere 41:259-263.

Dickinson N.M., Baker A.J.M., Doronila A., Laidlaw S., Reeves R.D., 2009. Phytoremediation of inorganics: realism and synergies. Int. J. Phytorem. 11:97-114.

Dimitriou I., Aronsson P., Weih M., 2006. Stress tolerance of five willow clones after irrigation with different amounts of landfill leachate. Biores. Tech. 97:150-157.

Domínguez M.T., Marañón T., Murillo J.M., Schulin R., Robinson R.D., 2008. Trace element accumulation in woody plants of the Guadiamar Valley, SW Spain: a large-scale phytomanagement case study. Env. Poll. 152:150-159.

EEA, 2007. Progress in management of contaminated sites. Report CSI 015. EEA Publ.

Fellet G., Marchiol L., Perosa D., Zerbi G., 2007. The application of phytoremediation technology in a soil contaminated by pyrite cinders - a preliminar pot experiment. Ecol. Eng. 31:207-214.

French C.J., Dickinson N.M., Putwain P.D., 2006. Woody biomass phytoremediation of contaminated brownfield land. Env. Poll. 141:387395.

Gove B,. Hutchinson J.J., Young S.D., Craigon J., McGrath S.P., 2002. Uptake of metals by plants sharing a rhizosphere with the hyperaccumulator Thlaspi caerulescens. Int. J. Phytorem. 4:267-281.

Grispen V.M.J., Nelissen H.J.M., Verkleij J.A.C., 2006. Phytoextraction with Brassica napus L.: a tool for sustainable management of heavy metal contaminated soils. Env. Poll. 144:77-83.

Hammer D., Keller C., 2003. Phytoextraction of Cd and Zn with Thlaspi caerulescens in field trials. Soil Use Manage. 19:144-149.

Hong-Bo S., Li-Ye C., Cheng-Jiang R., Hua L., Dong-Gang G., Wei-Xiang L., 2010. Understanding molecular mechanisms for improving phytoremediation of heavy metal-contaminated soils. Crit. Rev. Biotechnol. 30:23-30.

ISPRA, 2008. Annuario dei dati ambientali 2008. Roma, Italy.

ITRC, 2009. Phytotechnology Technical and Regulatory Guidance and Decision Trees, Revised. PHYTO-3. Washington, D.C.: Interstate Technology \& Regulatory Council, Phytotechnologies Team, Tech Reg Update.

Keller C., Hammer D., Kayser A., Richner W., Brodbeck M., Sennhauser M., 2003. Root development and heavy metal phytoextraction efficiency: comparison of different plant species in the field. Plant Soil 249:67-81.

King R.F., Royle A., Putwain P.D., Dickinson N.M., 2006. Changing contaminant mobility in a dredged canal sediment during a three-year phytoremediation trial. Env. Poll. 143 319-326.

Klang-Westin E., Eriksson J., 2003. Potential of Salix as phytoextractor for Cd on moderately contaminated soils. Plant Soil 249: 127-137.

Krämer U., 2010. Metal hyperaccumulation in plants. Annu. Rev. Plant Biol. 61:517-534.

Lasat M.M., 2002. Phytoextraction of toxic metals: A review of biological mechanisms. J. Environ. Qual. 31:109-120.

Li N.Y., Li Z.A., Zhuang P., Zou B., McBride M., 2009. Cadmium uptake from soil by maize with intercrops. Water Air Soil Pollut. 199:45-56.

Lichtfouse E., Hamelin M., Navarrete M., Debaeke P., Henri A., 2010. Emerging agroscience. Agron. Sustain. Dev. 30:1-10.
Lone M.I., He Z., Stoffella P.J., Yang X., 2008. Phytoremediation of heavy metal polluted soils and water: Progresses and perspectives. J Zhejiang Univ. Sci. B 9:210-220.

Macek T., Kotrba P., Svatos A., Novakova M., Demnerova K., Mackova M., 2009. Novel roles for genetically modified plants in environmental protection. Trends Biotechnol. 26:146-152.

Marchiol L., Fellet G., Perosa D., Zerbi G., 2007. Removal of trace metals by Sorghum bicolor and Helianthus annuus in a site polluted by industrial wastes: a field experience. Plant Physiol. Biochem., 45: 379-387.

Maxted A.P., Black C.R., West H.M., Crout N.M.J., McGrath S.P., Young S.D., 2007a. Phytoextraction of cadmium and zinc from arable soils amended with sewage sludge using Thlaspi caerulescens: development of a predictive model. Env. Poll. 150:363-372.

Maxted A.P., Black C.R., West H.M., Crout N.M.J., McGrath S.P., Young S.D. 2007b. Phytoextraction of cadmium and zinc by Salix from soil historically amended with sewage sludge. Plant Soil 290:157-172.

McGrath S.P., Lombi E., Gray C.W., Caille N., Dunham S.J., Zhao F.J., 2006. Field evaluation of $\mathrm{Cd}$ and $\mathrm{Zn}$ phytoextraction potential by the hyperaccumulators Thlaspi caerulescens and Arabidopsis halleri. Env. Poll. 141:115-125.

McGrath S.P., Zhao F.J., 2003. Phytoextraction of metals and metalloids from contaminated soils. Curr. Opin. Biotechnol. 14:277-282.

Meers E., Lamsal S., Vervaeke P., Hopgood M., Lust N., Tack F.M.G., 2005. Availability of heavy metals for uptake by Salix viminalis on a moderately contaminated dredged sediment disposal site. Env. Poll. 137:354-364.

Meers E., Van Slycken S., Adriaensen K., Ruttens A., Vangronsveld J., Du Laing G., Witters N., Thewys T., Tack F.M.G., 2010. The use of bio-energy crops (Zea mays) for 'phytoattenuation' of heavy metals on moderately contaminated soil: a field experiment. Chemosphere 78:33-41.

Mench M., Lepp N., Bert V., Schwitzguébel J-P., Gawronski S. W., Schröder P., Vangronsveld J. 2010. Successes and limitations of phytotechnologies at field scale: outcomes, assessment and outlook from COST Action 859. J Soils Sedim. 10:1039-1070.

Miller F.P. 2008. After 10,000 Years of Agriculture, Whither Agronomy? Agron. J., 100: 22-34.

Minguzzi C, Vergnano 0., 1948. Il contenuto di nichel nelle ceneri di Alyssum bertolonii Desv. Mem. Soc. Tosc. Sci. Nat. Ser. A 55:49-77.

Neugschwandtner R.W., Tlustoš P., Komárek M., Száková J., 2008. Nutrient mobilization and nutrient contents of Zea mays in response to EDTA additions to heavy-metal-contaminated agricultural soil. J. Plant Nutr. Soil Sci. 172:520-527.

Nie S.W., Gao W.S., Chen Y.Q., Sui P., Eneji E., 2010. Use of life cycle assessment methodology for determining phytoremediation potentials of maize-based cropping systems in fields with nitrogen fertilizer over-dose. J. Clean. Prod. 18:1530-1534.

Olson P.E., Castro A., Joern M., DuTeau N.M., Pilon-Smits E., Reardon K.F., 2008. Effects of agronomic practices on phytoremediation of an aged PAH-contaminated soil. J. Environ. Qual. 37:1439-1446.

Onwubuya K., Cundy A., Puschenreiter M., Kumpiene J., Bone B., Greaves J., Teasdale P., Mench M., Tlustos P., Mikhalovsky S., Waite S., Friesl-Hanl W., Marschner B., Müller I., 2009. Developing decision support tools for the selection of "gentle" remediation approaches. Sci. Tot. Environ. 407:6132-6142.

Pilon Smits E., 2005. Phytoremediation. Ann. Rev. Plant Biol. 56:15-39.

Prasad M.N.V., Freitas H., Fraenzle S., Wuenschmann S., Markert B., 2010. Knowledge explosion in phytotechnologies for environmental solutions. Env. Poll. 158:18-23.

Pulford D., Riddell-Black D., Stewart C., 2002. Heavy metal uptake by willow clones from sewage sludge-treated soil: the potential for phytoremediation. Int. J. Phytorem. 4:59-72.

Rosselli W., Keller C., Boschi K., 2003. Phytoextraction capacity of trees 
growing on a metal-contaminated soil. Plant Soil 256:265-272.

Santibáñez C., Verdugo C., Ginocchio R., 2008. Phytostabilization of copper mine tailings with biosolids: Implications for metal uptake and productivity of Lolium perenne. Sci. Total Environ. 395:1-10.

Schwartz C., Echevarria G., Morel J.L., 2003. Phytoextraction of cadmium with Thlaspi caerulescens. Plant Soil 249:27-35.

Schwitzguébel J.-P., Schröder P., 2009. Phytotechnologies to promote sustainable land use and improve food safety: outcomes and outlook from the European COST Action 859. Environ. Sci. Pollut. Res. 16:743-744.

Stals M., Thijssen E., Vangronsveld J., Carleer R., Schreurs S., Yperman J., 2009. Flash pyrolysis of heavy metal contaminated biomass from phytoremediation: Influence of temperature, entrained flow and wood/leaves blended pyrolysis on the behaviour of heavy metals. J. Anal. Appl. Pyrol. 87:1-7.

SUMATECS, 2009. Sustainable management of trace element contaminated soils - Development of a decision tool system and its evaluation for practical application. Final Research Report. Available from: www.snowman-era.net

UNEP, 2003. Phytotechnologies: A Technical Approach in Environmental Management. IETC Freshwater Management Series 7. ISBN No: 92-807-2253-0.

UNEP, 2009. Global Green New Deal. Policy Brief. United Nations Environment Programme.

USEPA, 2008. Green Remediation: Incorporating Sustainable Environmental Practices into Remediation of Contaminated Sites. EPA 542-R-08-002.
Vamerali T., Bandiera M., Coletto L., Zanetti F., Dickinson N.M., Mosca G., 2009. Phytoremediation trials on metal- and arsenic-contaminated pyrite wastes (Torviscosa, Italy). Env. Poll. 175:887-894.

Vamerali T., Bandiera M., Mosca G., 2010. Field crops for phytoremediation of metal-contaminated land. Environ. Chem. Lett. 8:1-17.

Van Nevel L., Mertens J., Oorts K., Verheyen K., 2007. Phytoextraction of metals from soils: How far from practice? Environ. Poll. 150:3440.

Vandecasteele B., Samyn J., De Vos B., Muys B., 2008. Effect of tree species choice and mineral capping in a woodland phytostabilization system: A case-study for calcareous dredged sediment landfills with an oxidized topsoil. Ecol. Eng. 32:263-273.

Vangronsveld J., Herzig R., Weyens N., Boulet J., Adriaensen K., Ruttens A., Thewys T., Vassilev A., Meers E., Nehnevajova E., van der Lelie D., Mench M., 2009. Phytoremediation of contaminated soils and groundwater: lessons from the field. Earth Environ. Sci. 16:765-794.

Vervaeke P., Luyssaert S., Mertens J., Meers E., Tack F.M.G., Lust N., 2003. Phytoremediation prospects of willow stands on contaminated sediment: a field trial. Env. Poll. 126:275-282.

Wei S., Zhou Q., Saha U.K., 2008. Hyperaccumulative characteristics of weed species to heavy metals. Water Soil Air Pollut. 192:173-181.

Wu G., Kang H., Zhang X., Shao H.; Chu L., Ruan C., 2010. A critical review on the bio-removal of hazardous heavy metals from contaminated soils: issues, progress, eco-environmental concerns and opportunities. J. Haz. Mat. 174:1-8. 